\title{
Heinrich Mann's Small Town Tyrant: The Grammar School Novel as a German Prototype of Academic Fiction
}

\section{Dieter Fuchs}

\section{Abstract}

This article considers the German Grammar School Novel from the first half of the twentieth century an all but forgotten Germanophone prototype of campus fiction. Whereas the Anglo-American campus novel of the 1970s, 80s and 90s features university professors as future-related agents of Western counterculture and free thought, the Grammar School Novel satirizes the German grammar school teacher known as Gymnasialprofessor as a representative of the past-related order of the autocratic German state apparatus from the beginning of the twentieth century. As Heinrich Mann's 1905 novel Professor Unrat / Small Town Tyrant (the source text of Marlene Dietrich's debut movie The Blue Angel) may be considered a foundational work of the German Grammar School Novel corpus, the main part of the article offers a sample analysis of this text.

Keywords: Anglo-American Campus Novel, German Grammar School Novel, Heinrich Mann, The Blue Angel, Marlene Dietrich 
This article focuses on the emergence and the cultural contact of Germanophone and Anglophone traditions of academic fiction.

Wolfgang Weiß notes that the professor-centred prototype of campus fiction emerged in the twentieth century. Before that period there were literary works focusing on student life. The life of university teachers, however, escaped representation. According to Weiß, the twentieth century discovery of the professor as a literary subject was triggered off by the levelling of class boundaries. ${ }^{1}$ Weiß considers the emergence of the professor in the field of campus fiction a class-bridging device, owing to the fact that it fosters plots which mingle the spheres of professorial and student life. Such a fusion of teacher and student life was not acceptable for texts written during the very class-conscious bourgeois period, which came to an abrupt end after the Great War. And it goes without saying that it is the social interaction between students and professors which makes modern and postmodern campus fiction so thrilling and fascinating.

Whereas the twentieth century discovery of the university professor as a future-oriented agent struggling against class boundaries takes place in the Anglophone campus novel ${ }^{2}$, the Germanophone literary tradition of the Grammar School Novel discovers the grammar school teacher as a representative of the past-related class system dominated by late-nineteenth and early twentieth century bourgeois culture. ${ }^{3}$ In the context of the German-speaking world, the term 'grammar school' refers to the institution of the Gymnasium, whose teachers had to be addressed as 'Herr Professor.' This professorial status of Germanophone Grammar School teachers is still upheld in contemporary Austria.

Focusing on the Grammar School Novel as a distinctly German-speaking prototype of early twentieth century academic fiction, the present article is going to argue that the Grammar School Novel documents the pre-history of the world reflected in the modern and postmodern Anglo-American campus novel.

In contrast to the university professors featured in Anglophone campus fiction, the German Grammar School professors are not presented as future-related agents of cultural change. Rather than that, the German Grammar School Novel satirizes the Gymnasialprofessor, owing to the fact that this stock character represents the past-related order of the autocratic German state apparatus dominated

1 Cf. Weiß 1994: 113-44.

2 Durrani (2000: 426) attributes the fact that the campus novel emerged in the Anglophone rather than Germanophone sphere to the fact "that there is no such thing as a German campus, and that there is an inability on the part of German academics to stand back and laugh at their own foibles." 
by the megalomanian Prussia-born Emperor William II and the industrial elite of the moneyed bourgeois middle classes.

The German Grammar School Novel emerged in the Wilhelmine period before and during the Great War. It continued in the era of the German Weimar Republic (1918-33). Although this republican interim was truly democratic, the past-related autocratic structures of thought remained fairly untouched in the mind-sets of many people. And although the bourgeois world de facto collapsed in 1918, many citizens continued to identify themselves in past-related terms. This greatly fostered the rise of the Nazi Dictatorship (1933-45). The Grammar School Novel tradition continued in the time after the Second World War until it came to an end as a result of Western counterculture in 1968/9. And this is the very period when the vogue of the (post)modern Anglo-American campus novel reaches a peak.

As the rise of the German Grammar School Novel coincides with the rise of cinema and film culture, many texts belonging to the Grammar School corpus were adapted for the screen and thus became popularized among a mass audience.

Important Grammar School Novels are Heinrich Mann's Small Town Tyrant (Professor Unrat 1905) and Ludwig Thoma's Rascal Stories (Lausbubengeschichten 1905); Friedrich Torberg's Disciple Gerber (Der Schüler Gerber 1930) and Heinrich Spoerl's Fire Tongue Punch (Die Feuerzangenbowle 1933); and up to a certain degree, one may also mention Hans Carossa's Metamorphoses of Youth (Verwandlungen einer Jugend 1928) and Erich Kästner's The Flying Classroom (Das Fliegende Klassenzimmer 1933). ${ }^{4}$ Whereas Fire Tongue Punch was adapted for the screen in 1944 to support the Nazi regime ${ }^{5}$, the movie adaptation of Heinrich Mann's Small Town Tyrant offers a great piece of anti-autoritarian satire. And even if one has never read Small Town Tyrant as a book, it is more than likely that one is familiar with its film adaptation The Blue Angel (1929/30) starring Marlene Dietrich.

As Heinrich Mann's Small Town Tyrant may be considered the seminal work of the German Grammar School Novel tradition, the main part of this

4 According to Thorsten Fitzon there is also the German literary tradition of the pupil's novel (Schülerroman) which encompasses texts such as Rainer Maria Rilke, Die Turnstunde (1899/1902), Emil Strauß, Freund Hein (1902), Hermann Hesse, Unterm Rad (1906), Robert Musil, Verwirrungen des Zögling Törleß (1906), Robert Walser, Jakob von Gunten (1909): cf. Bach 1922, Luserke 1999 \& Fitzon: http://www2.germanistik.uni-freiburg.de/fitzon/Bibliographie\%20Schuelerromane.pdf (21/07/2016). As Mira Miladinović-Zalaznik has elucidated, other samples from this text corpus include Franz Werfel, Der Abituriententag. Die Geschichte einer Jugendschuld (1928) and Florjan Lipuš, Zmote dijaka Tjaža (1972) - a Slovenian-Carinthian text which Peter Handke and Helga Mračnikar translated into German: Der Zögling Tjaž (1981).

5 Other film adaptations of Fire Tongue Punch emerged in 1934 and 1970. 
essay concentrates on this text. The central thesis is as follows: Whereas the Anglo-American campus novel offers a self-reflexive analysis of the university as an institution of liberal education, the German Grammar School Novel satirizes an institution that mis-considers education in terms of blind obedience and learning by heart rather than free and self-reflected thought. As the Grammar School Novel elucidates how the German Gymnasium indoctrinated the young generation to blindly obey their superiors representing the autocratic state apparatus, this type of fiction may be considered an anti-Bildungsroman, or anti-coming of age novel. Quite obviously, the German grammar school system only disseminated the social knowledge which was authorized by the state apparatus, and this dissemination of knowledge was endorsed by way of discipline and punishment.

The German Grammar School Novel thus offers a satire on a society whose collective knowledge is constituted by the un-reflected learning by heart of de-contextualized fragment-like bits and pieces from the literary canon; quotations which were collected in a bestselling anthology published by Georg Büchmann: Geflügelte Worte: der Citatenschatz des deutschen Volkes (1864). Büchmann's section on Shakespeare, for instance, lists text passages such as "The better part of valour is discretion" (90), "Sweet are the uses of adversity" (92), "And thereby hangs a tale" (95). As these textual fragments are presented without any contextualisation or explanation, they turn out to be both trite (if not to say meaningless) and universally applicable, and yet they are (mis)represented or objectified as allegedly universal truths. Heuristically speaking, the collective knowledge offered to the German people by Germany's leading anthologist turns out to be stupefying. In the context of the German Grammar School Novel as a satire on bourgeois educational discourse it may thus be considered symptomatic that Büchmann's breadwinning profession was that of a Gymnasialprofessor.

Of course, this brainwashing sort of pedagogy is designed to produce what the German state of the first half of the twentieth century considered its ideal subject: the inconspicuous, mediocre state official and functionary whose career is fostered by meekly adapting to the system rather than asking critical questions. This is the concept analysed in another novel by Heinrich Mann: Der Untertan (The Patrioteer 1914/18). 'Untertan' is the German term for the human subject subjected by the state. As a genius sticking out of the crowd would reveal the unreflected machinery of the Wilhelmine institutional apparatus, it is not the geniuses, but the un-inspired babbits that become the backbone of the state.

And this is the very situation Heinrich Mann's 1905 anti-Bildungsroman deals with: Small Town Tyrant focuses on the main character Professor Raat who works as a grammar school teacher. As Professor Raat has become subjected by the state as a result of his own grammar school education, he turns out to be the perfect representative of the political system which promoted his career in exchange of his 
willing suspension of critical awareness. Having entered a mock-Faustian contract in pursuit of uncritical mediocrity rather than overreaching curiosity, Professor Raat functions as a willing executioner of the state he represents. And it is owing to this collaborative if not to say corrupt disposition that the students consider their teacher a hypocrite rather than an authority: they hate him and play tricks on him whenever they can. It is owing to this hatred that they call him 'Unrat' rather than 'Raat.' 'Unrat' is the German word for garbage.

As Professor Raat hates his students owing to the fact that they deny his authority, he intends to break their will by way of discipline and punishment. Quite obviously, he does not want his students to think critically. Rather than that, he 'educates' them to unquestioningly learn and rehearse what others have said and thought. His approach to pedagogy thus attempts to reduce his disciples to what Professor Raat has become himself: a servile pedant without original ideas whom everybody hates, owing to the very reason that his example shows how the Wilhelmine state subjects its subjects by way of a brainwashing technique which inverts the classical maxim non scholae sed vitae discimus: we learn not for life, but in order to pass school and thus be reduced to loyal subjects without original knowledge.

Heinrich Mann's novel, however, does not only satirize the hypocritical state official and the institutional apparatus he represents. It first of all offers an analysis of the system that has turned Professor Raat into such an unlikeable character. It is not only him but also his fellow citizens, subjected by the same apparatus, who turn out to be the main target of satire: as soon as Professor Raat begins to stick out of the crowd and seizes to collaborate with social mainstream values, he becomes stigmatized and destroyed by his peers.

When the life-long loner Professor Raat falls in love with a femme fatale-like social outcast and gives in to sexual passion, he loses not only his reputation but also his job: as foregrounded in the film adaptation The Blue Angel, he feels helplessly attracted to an uneducated but very good-looking young woman who works as a stripper and probably prostitutes herself in an ill-reputed bar. Rather than liberate himself in an act of individualization, however, the simple-minded Raat substitutes his slave-like position as a state servant by his erotic dependence on the girl's sexualized body. In other words, the servile state official discards his patriarchal Lord and master Emperor William II in favour of his new, increasingly dominant and unruly mistress.

Moving from societal analysis in general to the more specific context of the world of academia, Professor Raat's main problem lies in the fact that a young and sexually attractive woman intrudes into an institution monopolized by old men. Even if the rather vulgar young woman is not fashioned as a student, Professor Raat's dilemma triggered off by this encounter may be attributed to 
the following problem: as a teacher, he represents an educational system which used to be monopolized by the church in the past. In pre-eighteenth century Europe, public knowledge was controlled by the church: as the schools were run by monks and priests, only the initiated clerical elite had access to scholarly knowledge. And it is owing to this clerical, or monastic background that teachers and academics may be considered secularized priest-figures - hence Heinrich Mann's presentation of Professor Raat as a celibate loner excluded from the world of everyday married life. ${ }^{6}$

When Professor Raat encounters the pleasures of uninitiated secular lay life represented by the seductive girl, his professional ethos requires to retreat, monklike, into the splendid isolation of the celibate sphere of the grammar school as a secularized monastery. As the Church Father Origines and the main character from J. M. R. Lenz's German Sturm und Drang drama The Tutor (Der Hofmeister 1774) suggest, traditional pedagogic discourse recommends the following solution to such a problem: to satisfy and safeguard the all-masculine priest-like world of academia, the afflicted professor has to resist sexual attraction, and if he can't resist, Eunuch-like, undo his unruly flesh in an act of voluntary self-castration.

As Professor Raat does not control - or castrate - himself, he loses his job and is excluded from the academic community of secularized priest figures. As he loses his salary in this way and has to live on his girl friend's income, his mistress reduces him to her domestic servant who has to do household-chores and procure moneyed lovers as her pimp. Professor Raat is thus reduced to a horned and henpecked husband: although he rejected the academic call for monkish chastity - or Eunuch-like self-castration -, he is denied his virility in the end. Rather than engaging in scholarly discourse among an initiate community of all-masculine thought, he has to live on selling his spouse's body to both sexually and financially speaking, more potent laymen from the world beyond the protected academic ivory tower of the Gymnasium.

As has been shown in this article, the German Grammar School Novel exemplified by Heinrich Mann's Small Town Tyrant functions as an experimental field of anti-autoritarian social and political satire in the first half of the twentieth century. In the time after the Second World War, however, the German Grammar School Novel loses it satirical grip. It becomes trivialized and adapted for shallow mass entertainment. Especially in the late 1960s and early 1970s, the

6 As a satirical twist, Raat's lifelong celibacy is interrupted when he marries a wealthy widow to finance his teacher training course: like a prostitute, the corrupt Raat exchanges sex for money. When his spouse dies, Raat returns to his celibate life. 
Grammar School Novel is reduced to farce to be adapted for the movie industry. In a never-ending cinematographic series entitled The Rascals from the First Row (Die Lümmel von der ersten Bank 1967-72), for instance, the Grammar School Novel is redefined in terms of slapstick comedy. ${ }^{7}$

An important reason for this trivialisation may be attributed to the circumstance that left-wing counterculture begins to infiltrate the German establishment in the Summer of '69 and that the cultural and political elite tries to trivialize and undo the work of Western counterculture by transforming the anti-establishment satire of the Grammar School Novel into meaningless mass entertainment. As a part of Cold Warfare, Western Germanophone middle class culture tries to keep the leftist countercultural impact as harmless - and at as great a distance - as possible. As the cultural identity of the Germanophone elite remains nostalgically imbued with the heydays of its bourgeois past, the Western German countries do their best to avoid any serious countercultural debate.

In contrast to the German Grammar School Novel, the work of Western counterculture - which triggered a flood of cultural, literary and philosophical theory - is ardently debated in the postmodern Anglo-American campus novels written in the 1970s and 1980s. In contrast to the Anglo-American tradition - which from then on becomes the standard prototype of academic fiction to be imitated throughout the western world including the German-speaking countries -, the Germanophone Grammar School Novel becomes an outdated relic of the past. It becomes as obsolete as its main target of satire: the decline and fall of the autocratic German state apparatus and its bourgeois elite in the first half of the twentieth century.

\section{REFERENCES}

\section{Primary Sources}

Büchmann, Georg, Georg Büchmann's Geflügelte Worte: der Citatenschatz [sic!] des deutschen Volkes. Berlin: Haude \& Spenersche Buchhandlung, 1864.

Carossa, Hans, Verwandlungen einer Jugend. 2nd ed. Frankfurt am Main: Insel-Verlag, 1985.

Hesse, Hermann, Demian: die Geschichte von Emil Sinclairs Jugend. Frankfurt am Main: Suhrkamp, 2000.

7 One of the very few non-trivialized Grammar School Novels written in this period is Florjan Lipuš Zmote dijaka Tjaža (1972) - the already mentioned Slovenian-Carinthian novel which Peter Handke and Helga Mračnikar translated into German: Der Zögling Tjaž (1981). Focusing on the author's adolescent experiences with the Austrian educational system, this text features life in the very elitist Tanzenberg boarding school. Like many other Austrian artists such as Gustav Januš and Erich Prunč, this boarding school was also attended by Peter Handke - the co-translator of Zmote dijaka Tjaža. 
Hesse, Hermann. Unterm Rad. Frankfurt am Main: Suhrkamp, 2002.

Kästner, Erich, Das Fliegende Klassenzimmer: ein Roman für Kinder. $3^{\text {rd }}$ ed. Wien: Ueberreuter, 1950.

Lenz, Jakob Michael Reinhold, Der Hofmeister oder Vorteile der Privaterziehung: eine Komödie. Frankfurt am Main: Suhrkamp, 2009.

Lipuš Florjan, Zmote dijaka Tjaža. Maribor: Obzorja, 1972; Der Zögling Tjaž. Translated into German by Peter Handke \& Helga Mračnikar. Wien: Residenz-Verlag, 1981.

Mann, Heinrich, Der Untertan. Ungekürzte Ausgabe, $21^{\text {st }}$ ed. München: DTV, 1980.

Mann, Heinrich. Professor Unrat oder Das Ende eines Tyrannen. Frankfurt am Main: Fischer, 2002.

Mann, Heinrich. Small Town Tyrant. 1st. Ed. New York: Creative Age Press, 1944.

Musil, Robert, Die Verwirrungen des Zögling Törleß. Reinbek: Rowohlt, 1995.

Rilke, Rainer Maria, "Die Turnstunde.” Sämtliche Werke. Hrsg. Rilke-Archiv \& Ruth Sieber-Rilke besorgt durch Ernst Zinn. Frankfurt am Main: Insel Verlag, Bd. 4. (1961): 602-3.

Spoerl, Heinrich, Die Feuerzangenbowle: Eine Lausbüberei in der Kleinstadt. Düsseldorf: Droste, 1956.

Strauß, Emil, Freund Hein. Eine Lebensgeschichte. Stuttgart: Reclam, 1995.

Thoma, Ludwig, Lausbubengeschichten und andere Erzäblungen. Wien: Buchgemeinschaft Donauland, 1964.

Torberg, Friedrich, Der Schüler Gerber. Wien: Buchgemeinschaft Donauland, 1999.

Walser, Robert, Jakob von Gunten: ein Tagebuch. Zürich: Suhrkamp, 1985.

Wedekind, Frank, Früblings Erwachen. Stuttgart: Reclam, 1996.

Werfel, Franz, Der Abituriententag. Die Geschichte einer Jugendschuld. Wien: Paul Zsolnay Verlag, 1928.

\section{Secondary Sources}

Bach J., Der deutsche Schülerroman und seine Entwicklung. Diss. Münster, 1922.

Durrani, Osman, "The Campus and its Novel: Dietrich Schwanitz's Literary Exploration of German University Life." In Stark, Susanne (Ed.), The Novel in Anglo-German Context: Cultural Cross-Currents and Affinities. Amsterdam: Rodopi, 2000. 435-436.

Luserke, Matthias, Schule erzählt. Literarische Spiegelbilder im 19. und 20. Jahrbundert. Göttingen: V\&R, 1999.

Mews, Siegfried, "Martin Walsers Brandung: Ein deutscher Campus Roman?" The German Quarterly 60.2 (1987): 220-236. 
Weiß, Wolfgang, Der Anglo-Amerikanische Universitätsroman. Eine Historische Skizze. 2nd ed. Darmstadt: WBG, 1994.

Dieter Fuchs

University of Vienna, Austria dieter.fuchs@univie.ac.at

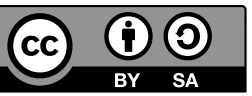

\section{Roman Small Town Tyrant Heinricha Manna: gimnazijski roman kot nemški prototip akademske proze}

Članek analizira nemški gimnazijski roman prve polovice 20. stoletja kot pomemben germanofonski prototip univerzitetne proze. Roman Heinricha Manna Small Town Tyrant predstavlja v tem smislu temeljno delo nemškega korpusa gimnazijskega romana in je bil tudi predloga za film Modri angel v katerem je debitirala Marlene Dietrich.

Ključne besede: angloameriška univerzitetna kampus proza, nemški gimnazijski roman, Heinrich Mann, The Blue Angel, Marlene Dietrich 